\title{
Vermiconversion of biogas plant slurry and parthenium weed mixture to manure
}

\author{
Anoop Yadav ${ }^{1}$ V. K. Garg ${ }^{2,3}$
}

Received: 8 June 2016/Accepted: 14 October 2016/Published online: 22 October 2016

(c) The Author(s) 2016. This article is published with open access at Springerlink.com

\begin{abstract}
Purpose Parthenium hysterophorus is one among the most troublesome weeds at the global level. It is mainly controlled by chemical methods. The scientific community is in search of new but non-destructive approaches for its management. Vermicomposting is one among the promising technologies for the management of organic fraction of solid wastes. This study was undertaken to assess the vermicomposting of parthenium weed mixed with biogas plant slurry under laboratory conditions.

Method Six different combinations of biogas plant slurry and parthenium were fed to worms in vermibins under controlled laboratory conditions for 60 days. Various physico-chemical parameters before and after vermicomposting were evaluated. Worm biomass production was also monitored periodically during the experimentation period.

Results The EC, TCa and NPK content increased significantly after vermicomposting, accompanied by substantial reduction in organic carbon content. $\mathrm{C}$ : $\mathrm{N}$ ratio was reduced to less than 20 . Heavy metals $(\mathrm{Fe}, \mathrm{Zn}, \mathrm{Ni}, \mathrm{Cu}, \mathrm{Cr}$ and $\mathrm{Pb}$ ) concentration was higher in vermicompost than in initial waste mixtures. Parthenium weed addition to worm feed was not supportive to the worm growth and fecundity.
\end{abstract}

V. K. Garg

vinodkgarg@yahoo.com

1 Department of Environmental Science, Central University of Haryana, Mahendergarh, Haryana, India

2 Centre for Environmental Sciences and Technology, Central University of Punjab, Bathinda, Punjab 151001, India

3 Department of Environmental Science and Engineering, Guru Jambheshwar University of Science and Technology, Hisar, Haryana 125001, India
It was inferred from the results that vermicomposting may be an efficient biological approach to convert partheniumspiked biogas plant slurry into nutrient-rich manure.

Keywords Biogas plant slurry - Eisenia fetida .

Parthenium hysterophorus $\cdot$ Vermicompost $\cdot$ Weed $\cdot$ Worm growth

\section{Introduction}

The expansive use of chemical fertilizers in agriculture has led to imbalance in natural ecosystems to such an extent that the world has now realized the importance of ecofriendly cultivation practices in agriculture and the need for utilization of naturally available organic materials of plant and animal origin and refuse of agro-based industries for sustainable farming. It is evident from the available literature that weeds are mainly controlled by destructive methods. Little attention has been paid to them as a biomass resource. Weeds are valuable resources and available free of cost, growing without cultivation and irrigation (Kishore et al. 2010).

Parthenium hysterophorus L. is a highly prolific and pernicious invasive weed species reported in India and several other countries. The weed has been unintentionally introduced in India and within the last few decades, it has achieved the status of most hazardous and problematic weed (Yadav and Garg 2013). Now it is a common weed along roadsides, riverbanks around cropping land and on wastelands, where it predominantly invades disturbed habitats and negatively affects agricultural production. The weed is considered as a noxious weed due to its adaptability to a wide range of soil and climatic conditions, rapid seed germination, seed persistence in soil seed banks, 
flexibility in life cycle (short and extended), strong competitiveness, allelopathic effects on other plants and health effects on animals as well as on human beings.

Parthenium is one of the most dreaded weeds and can germinate throughout the year. Parthenin is the toxic substance present in it and is the causative factor for several health problems (Nallathambi 1998). Several authors have reported the adverse impacts of Parthenium hysterophorus on agriculture (Kishore et al. 2010; Khaliq et al. 2015). It reduces production from livestock by causing various health problems and by causing scarcity of animal fodder by invading pasturelands. P. hysterophorus is poisonous to livestock when it is consumed or repeatedly in contact with the weed. Those animals can encounter death, rashes on their body and udders, alopecia, loss of skin pigmentation, allergic skin reactions, dermatitis, diarrhoea, anorexia, pruritus (Bezuneh 2015).

The invasion of the weed to agriculture is a serious problem. Several control methods (chemical, biological, mechanical and integrated) are being used and most of the methods are not successful due to rapid re-infestation of the plant. None of the method is practically effective for its eradication and control. The chemical control method depends on herbicides, which leads to environmental problems and affects non-target plants. Biological methods (such as pests, competitive plants, etc.) have their own restrictions. Physical methods such as ploughing and uprooting are labour intensive. Burning has adverse effects on living organisms and the environment.

Vermicomposting is biological transformation of organic waste into a stabilized product that can be applied in agricultural fields without detrimental effects on plant growth (Ravindran et al. 2015, Pigatin et al. 2016). Yadav and Garg (2011) have reported that Parthenium hysterophorus can be effectively converted into vermicompost if mixed in appropriate quantities with animal dung. The present study is hypothesized that vermicomposting of parthenium weed spiked with biogas plant slurry (BPS) could be an alternative option for weed control. Rajiv et al. (2013) reported that if Parthenium hysterophorus is amended with cow dung then Parthenin free vermicompost can be produced using E. eugeniae. The phenol contents were reduced by $32-48 \%$ during vermicomposting. In various studies conducted on vermicomposting of Parthenium hysterophorus, mainly cow dung has been used as spiking material (Table 1). Therefore, studies are required on other organic wastes also to explore their potential in the vermicomposting of Parthenium hysterophorus as spiking material. Keeping this in view present study has been conducted to investigate the bioconversion of Parthenium hysterophorus spiked with biogas plant slurry using epigeic worm Eisenia fetida.

\section{Materials and methods}

Biogas plant slurry (BPS) was acquired from a $100 \mathrm{~m}^{3}$ capacity biogas plant located at village Ladwa, Hisar, India. In this plant, cow dung mixed with canal water is used as feed. Green plants of Parthenium hysterophorus $(\mathrm{PH})$ growing along roadside were cut about $5.0 \mathrm{~cm}$ above the ground for use in the experiment (Fig. 1). The weed plants were cut into small pieces $(2-3 \mathrm{~cm})$ before use in experiments. Eisenia fetida hatchlings maintained in the laboratory in stock cultures were used for experimentation. E. fetida was used in the experiments due to its well-

Table 1 Studies conducted in past on the vermicomposting of Parthenium hysterophorus (PH)

\begin{tabular}{|c|c|c|c|c|}
\hline Waste mixture & $\begin{array}{l}\text { Earthworm } \\
\text { species }\end{array}$ & $\begin{array}{l}\text { Period of } \\
\text { experiment }\end{array}$ & Key findings & References \\
\hline $\begin{array}{l}\text { Parthenium hysterophorus mixed } \\
\text { with cow dung }\end{array}$ & $\begin{array}{r}\text { Eisenia } \\
\text { fetida }\end{array}$ & 18 weeks & $\begin{array}{l}\text { Among the parthenium containing treatments, } 25 \% \text { parthenium } \\
\text { and } 75 \% \mathrm{CD} \text { containing treatment was optimum for the } \\
\text { growth and reproduction of } E \text {. fetida }\end{array}$ & $\begin{array}{l}\text { Yadav and } \\
\text { Garg } \\
(2011)\end{array}$ \\
\hline $\begin{array}{l}\text { Parthenium hysterophorus mixed } \\
\text { with cow dung }\end{array}$ & $\begin{array}{l}\text { Eudrilus } \\
\text { eugeniae }\end{array}$ & 45 days & $\begin{array}{l}\text { Parthenium mediated vermicompost showed an increase in plant } \\
\text { nutrition, but decrease in organic carbon and phenol contents } \\
\text { when it was compared to initial feed mixtures. The results } \\
\text { indicated that Parthenin toxin and phenols can be eradicated } \\
\text { via vermicomposting if } P \text {. hysterophorus is mixed with } \\
\text { appropriate quantity of cow dung }\end{array}$ & $\begin{array}{c}\text { Rajiv et al. } \\
\text { (2013) }\end{array}$ \\
\hline $\begin{array}{l}\text { Cow dung, food industry sludge, } \\
\text { water hyacinth and parthenium }\end{array}$ & $\begin{array}{r}\text { Eisenia } \\
\text { fetida }\end{array}$ & 13 week & $\begin{array}{l}\text { The final vermicomposts were homogenous and rich in important } \\
\text { plant nutrients (NPK). The wastes can be converted into good } \\
\text { quality manure by vermiprocessing, which indicated their } \\
\text { agricultural values as a soil conditioner if mixed with weeds in } \\
\text { appropriate ratios }\end{array}$ & $\begin{array}{l}\text { Yadav and } \\
\text { Garg } \\
(2013)\end{array}$ \\
\hline $\begin{array}{l}\text { Parthenium, farm wastes, goat } \\
\text { manure, poultry manure and cow } \\
\text { dung }\end{array}$ & $\begin{array}{l}\text { Eisenia } \\
\text { foetida }\end{array}$ & 60 days & $\begin{array}{l}\text { Addition of different farm and animal wastes helped to degrade } \\
\text { the parthenium and improve the nutrient value }\end{array}$ & $\begin{array}{l}\text { Yadav } \\
\quad(2015)\end{array}$ \\
\hline
\end{tabular}




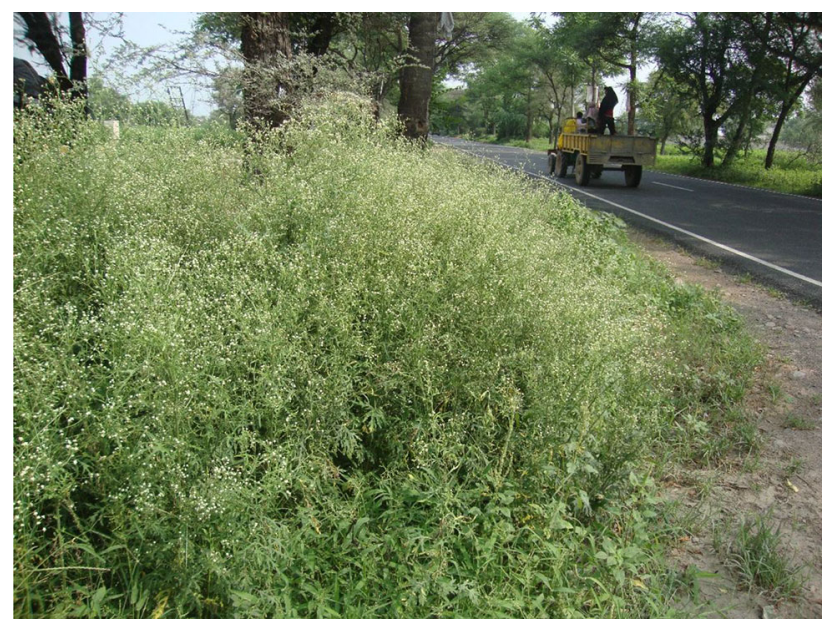

Fig. 1 Parthenium hysterophorus growing along road side

Table 2 Initial physico-chemical characteristics of Biogas Plant Slurry (BPS) and Parthenium hysterophorus (PH)

\begin{tabular}{llcc}
\hline S. No. & Parameters & BPS & PH \\
\hline 1 & pH & $8.8 \pm 0.2$ & $6.09 \pm 0.1$ \\
2 & EC $(\mathrm{dS} / \mathrm{m})$ & $2.23 \pm 0.04$ & $5.54 \pm 0.15$ \\
3 & TOC $(\mathrm{g} / \mathrm{kg})$ & $431 \pm 14$ & $462 \pm 26$ \\
4 & TKN $(\mathrm{g} / \mathrm{kg})$ & $6.4 \pm 0.3$ & $7.7 \pm 0.23$ \\
5 & TAP $(\mathrm{g} / \mathrm{kg})$ & $2.29 \pm 0.1$ & $2.12 \pm 0.3$ \\
6 & TK $(\mathrm{g} / \mathrm{kg})$ & $7.8 \pm 0.3$ & $1.8 \pm 0.05$ \\
7 & $\mathrm{TCa}(\mathrm{g} / \mathrm{kg})$ & $1.87 \pm 0.08$ & $1.55 \pm 0.01$ \\
8 & $\mathrm{C}: \mathrm{N} \mathrm{ratio}$ & $67.35 \pm 3.8$ & $60.0 \pm 3.5$ \\
9 & $\mathrm{Fe}(\mathrm{mg} / \mathrm{kg})$ & $5670 \pm 220$ & $4747 \pm 19$ \\
10 & $\mathrm{Zn}(\mathrm{mg} / \mathrm{kg})$ & $172.5 \pm 4.6$ & $131.7 \pm 3.6$ \\
11 & $\mathrm{Ni}(\mathrm{mg} / \mathrm{kg})$ & $7.4 \pm 0.37$ & $5.6 \pm 0.09$ \\
12 & $\mathrm{~Pb}(\mathrm{mg} / \mathrm{kg})$ & $7.7 \pm 0.40$ & $7.9 \pm 0.4$ \\
13 & $\mathrm{Cr}(\mathrm{mg} / \mathrm{kg})$ & $100.8 \pm 1.3$ & $78.1 \pm 0.2$ \\
14 & $\mathrm{Cu}(\mathrm{mg} / \mathrm{kg})$ & $31.7 \pm 1.4$ & $25.7 \pm 0.55$ \\
\hline
\end{tabular}

The data represent the mean \pm standard deviation of three replicates

established potential for vermicomposting of various compostable organic materials such as agricultural wastes, weeds, animal wastes and industrial wastes. The physicochemical characteristics of the BPS and $\mathrm{PH}$ are given in Table 2.

\section{Experimental design}

Six circular plastic vermibins were filled with $4 \mathrm{~kg}$ of waste mixture (on dry weight basis) containing different proportion of BPS and PH. The following vermibins were established:

Vermibin 1: $100 \%$ BPS

Vermibin 2: $90 \% \mathrm{BPS}+10 \% \mathrm{PH}$
Vermibin 3: $80 \%$ BPS $+20 \% \mathrm{PH}$

Vermibin $4: 70 \%$ BPS $+30 \% \mathrm{PH}$

Vermibin 5: $60 \%$ BPS $+40 \% \mathrm{PH}$

Vermibin 6: $50 \% \mathrm{BPS}+50 \% \mathrm{PH}$

All the vermibins were allowed to undergo composting for 3 weeks, to eliminate the volatile gases and make the waste mixtures palatable to worms. After composting, 200 unclitellated hatchlings were added in each vermibin. All the vermibins were kept in the dark in laboratory at 20-25 ${ }^{\circ} \mathrm{C}$, maintaining $60-80 \%$ moisture and covered with jute cloth. Samples of the waste were drawn at 0 day (initial) and day 60 (at end) from each vermibin. The zero day refers to the day of inoculation of worms after 3-weeks composting. The samples so collected were free from earthworms, hatchlings and cocoons. The samples were dried in shade at room temperature prior to physicochemical and heavy metal analysis.

\section{Physico-chemical and statistical analyses}

A 1:10 (w/v) suspension of each sample with distilled water was prepared for $\mathrm{pH}$ and electrical conductivity (EC) determination. Total organic carbon (TOC), Total Kjeldhal nitrogen (TKN) and Total available phosphorus (TAP) were determined as reported by Nelson and Sommers (1982), Bremner and Mulvaney (1982) and Bear (1964) respectively. Total potassium (TK) and Total calcium (TCa) were determined by flame photometer after digesting the samples. Heavy metals $(\mathrm{Fe}, \mathrm{Cu}, \mathrm{Zn}, \mathrm{Ni}, \mathrm{Pb}$ and $\mathrm{Cr}$ ) were determined by atomic absorption spectrophotometer (AAS) (AAS 6300 Shimadzu, Japan). The samples were digested in conc. $\mathrm{HNO}_{3}$ and $\mathrm{HClO}_{4}(9: 1, \mathrm{v} / \mathrm{v})$ prior to heavy metal determination. $\mathrm{C}: \mathrm{N}$ ratio was calculated from TOC and TKN values.

The results are presented as the average of three replicates. The data was analysed by One-way analysis of variance (ANOVA). The post hoc Tukey's $t$ test was used to evaluate the significant alterations among unlike treatments for studied factors.

\section{Results and discussion}

\section{Nutrient quality of vermicomposts}

The physico-chemical properties of wastes were considerably modified by the earthworms. The worms had reduced the particle size of organic matter, thus reducing the volume and mass of initial quantities taken in the vermibins. The vermicompost was fine, homogeneous, light and blackish in colour. During vermicomposting, the ingested material is fragmented and homogenized by the worms in 
so doing the surface area is increased for microbial action. The microbial communities are primarily responsible for extra-cellular enzymes required for waste mineralization in the vermicomposting bins (Edwards and Fletcher 1988).

Initial $\mathrm{pH}$ of wastes varied from 8.8 to 7.4 in different vermibins. Whereas $\mathrm{pH}$ of vermicomposts was in the range of 6.95-7.23 which is lesser than initial $\mathrm{pH}$ of wastes (Table 3). The $\mathrm{pH}$ variations were not significantly different between different waste mixtures $(P>0.05)$. The lowering of $\mathrm{pH}$ may also be due to the production of carbon dioxide, ammonia, nitrates and organic acids during the worm activity (Suthar 2010). The $\mathrm{pH}$ reduction may also be contributed to $\mathrm{N}$ and $\mathrm{P}$ mineralization (Ndegwa et al. 2000).

EC of vermicomposts was higher than initial wastes (Table 3). The EC of waste mixtures and vermicomposts was in the range of 2.3-3.8 $\mathrm{dS} \mathrm{m}^{-1}$ and 3.75-4.66 $\mathrm{dS} \mathrm{m}^{-1}$, respectively. Statistically, the EC contents in vermibin 1, 2, 3 and 4 were not significantly different from each other $(P>0.05)$. EC was maximum in vermibin 1 and the minimum in vermibin 6 . This increase in EC may be due to increased level of soluble salts due to mineralization of the waste by worms and microorganisms.

Phosphorus is an essential nutrient from manurial point of view in vermicompost. TAP was 29.5 to $75 \%$ higher in vermicomposts than initial waste mixtures (Table 3). The TAP content of initial waste mixtures was in the range of $2.20-2.31 \mathrm{~g} \mathrm{~kg}^{-1}$, while, TAP in vermicomposts was in the range of $2.85-4.06 \mathrm{~g} \mathrm{~kg}^{1}$. Lee (1992) reported that the organic materials pass through the gut of earthworms then some of phosphorus being converted to such forms that are available to plants. Mineralization and mobilization of Phosphorus due to bacterial and earthworm's activity may be responsible for increase in TAP (Goswami et al. 2013).

TK and TCa contents were marginally greater in the vermicomposts than waste mixtures (Tables 2 and 3 ). Kaviraj and Sharma (2003) have reported that various acids produced by the worms during vermicomposting process may be responsible for the conversion of insoluble potassium into soluble potassium. Increase in TCa content may be credited to the mineralization of waste in by worms during vermicomposting. Roca-Pérez et al. (2009) have reported that loss of organic matter by degradation, evaporation and volatilization also contributes to increased quantities of the minerals.

TOC content was 25.6 to $33.9 \%$ lesser in the vermicomposts than initial waste mixtures. TOC loss was highest in vermibin 1 and lowest in vermibin 5. Initial TOC content in the waste mixtures was in the range of 430 to $440 \mathrm{~g} \mathrm{~kg}^{-1}$, while in the vermicomposts was in the range of $284-328 \mathrm{gkg}^{-1}$ (Fig. 2). The collective action of the worms and microorganisms may be responsible for the loss of organic carbon from the organic wastes in the form of $\mathrm{CO}_{2}$ (Prakash and Karmegam 2010). Suthar (2006) has reported that microbial respiration also contributes to the loss of organic carbon during vermicomposting.

Total Kjeldahl nitrogen (TKN) was higher in vermicomposts than the initial waste mixtures. The TKN content of waste mixtures was in the range of 6.48 to $7.50 \mathrm{~g} \mathrm{~kg}^{-1}$ (Fig. 3). Whereas in vermicomposts it ranged from 19.3 to $29.4 \mathrm{~g} \mathrm{~kg}^{-1}$. The differences in TKN content after vermicomposting between waste mixtures except that between
Table 3 Physico-chemical characteristics of initial waste mixtures and vermicomposts (mean $\pm \mathrm{SD}, n=3$ )

\begin{tabular}{llllll}
\hline $\begin{array}{l}\text { Vermibin } \\
\text { no. }\end{array}$ & $\mathrm{pH}$ & $\mathrm{EC}$ & $\mathrm{TAP}$ & $\mathrm{TK}$ & $\mathrm{TCa}$ \\
\hline \multicolumn{1}{l}{ Initial waste mixtures } & & & & \\
1 & $8.8 \pm 0.22$ & $2.3 \pm 0.08$ & $2.30 \pm 0.20$ & $7.8 \pm 0.15$ & $1.88 \pm 0.12$ \\
2 & $8.5 \pm 0.10$ & $2.5 \pm 0.10$ & $2.31 \pm 0.01$ & $7.2 \pm 0.20$ & $1.82 \pm 0.03$ \\
3 & $8.2 \pm 0.02$ & $2.9 \pm 0.13$ & $2.26 \pm 0.04$ & $6.6 \pm 0.15$ & $1.81 \pm 0.12$ \\
4 & $8.0 \pm 0.11$ & $3.3 \pm 0.20$ & $2.29 \pm 0.06$ & $6.0 \pm 0.30$ & $1.70 \pm 0.13$ \\
5 & $7.7 \pm 0.03$ & $3.6 \pm 0.01$ & $2.20 \pm 0.01$ & $5.4 \pm 0.15$ & $1.73 \pm 0.02$ \\
6 & $7.4 \pm 0.20$ & $3.8 \pm 0.20$ & $2.20 \pm 0.03$ & $4.8 \pm 0.20$ & $1.70 \pm 0.02$ \\
Vermicompost & & & & & \\
1 & $6.95 \pm 0.17 \mathrm{a}$ & $3.75 \pm 0.07 \mathrm{a}$ & $3.51 \pm 0.06 \mathrm{~b}$ & $8.18 \pm 0.02 \mathrm{f}$ & $4.0 \pm 0.10 \mathrm{c}$ \\
2 & $7.10 \pm 0.20 \mathrm{a}$ & $3.96 \pm 0.10 \mathrm{a}$ & $4.06 \pm 0.03 \mathrm{~d}$ & $7.76 \pm 0.01 \mathrm{e}$ & $2.90 \pm 0.05 \mathrm{~b}$ \\
3 & $7.23 \pm 0.09 \mathrm{a}$ & $3.78 \pm 0.33 \mathrm{a}$ & $3.83 \pm 0.08 \mathrm{c}$ & $7.12 \pm 0.12 \mathrm{~d}$ & $2.85 \pm 0.2 \mathrm{~b}$ \\
4 & $7.11 \pm 0.01 \mathrm{a}$ & $4.02 \pm 0.01 \mathrm{a}$ & $3.56 \pm 0.08 \mathrm{~b}$ & $6.23 \pm 0.02 \mathrm{c}$ & $2.12 \pm 0.5 \mathrm{a}$ \\
5 & $7.18 \pm 0.04 \mathrm{a}$ & $4.65 \pm 0.09 \mathrm{~b}$ & $2.85 \pm 0.06 \mathrm{a}$ & $5.93 \pm 0.08 \mathrm{~b}$ & $2.11 \pm 0.09 \mathrm{a}$ \\
6 & $7.10 \pm 0.21 \mathrm{a}$ & $4.66 \pm 0.14 \mathrm{~b}$ & $2.88 \pm 0.03 \mathrm{a}$ & $5.38 \pm 0.05 \mathrm{a}$ & $2.07 \pm 0.06 \mathrm{a}$ \\
\hline
\end{tabular}

Units of all the parameters except $\mathrm{pH}$ and $\mathrm{EC}$ are in $\mathrm{g} \mathrm{kg}^{-1}$. The EC values are in $\mathrm{dS} \mathrm{m}^{-1}$. Mean values followed by the same letter(s) in a column within the raw mixtures or the vermicomposts are not significantly different at $P<0.05$ 
Fig. 2 TOC content of initial waste mixtures and vermicomposts in different vermibins

Fig. 3 TKN content of initial waste mixtures and vermicompost in different vermibins
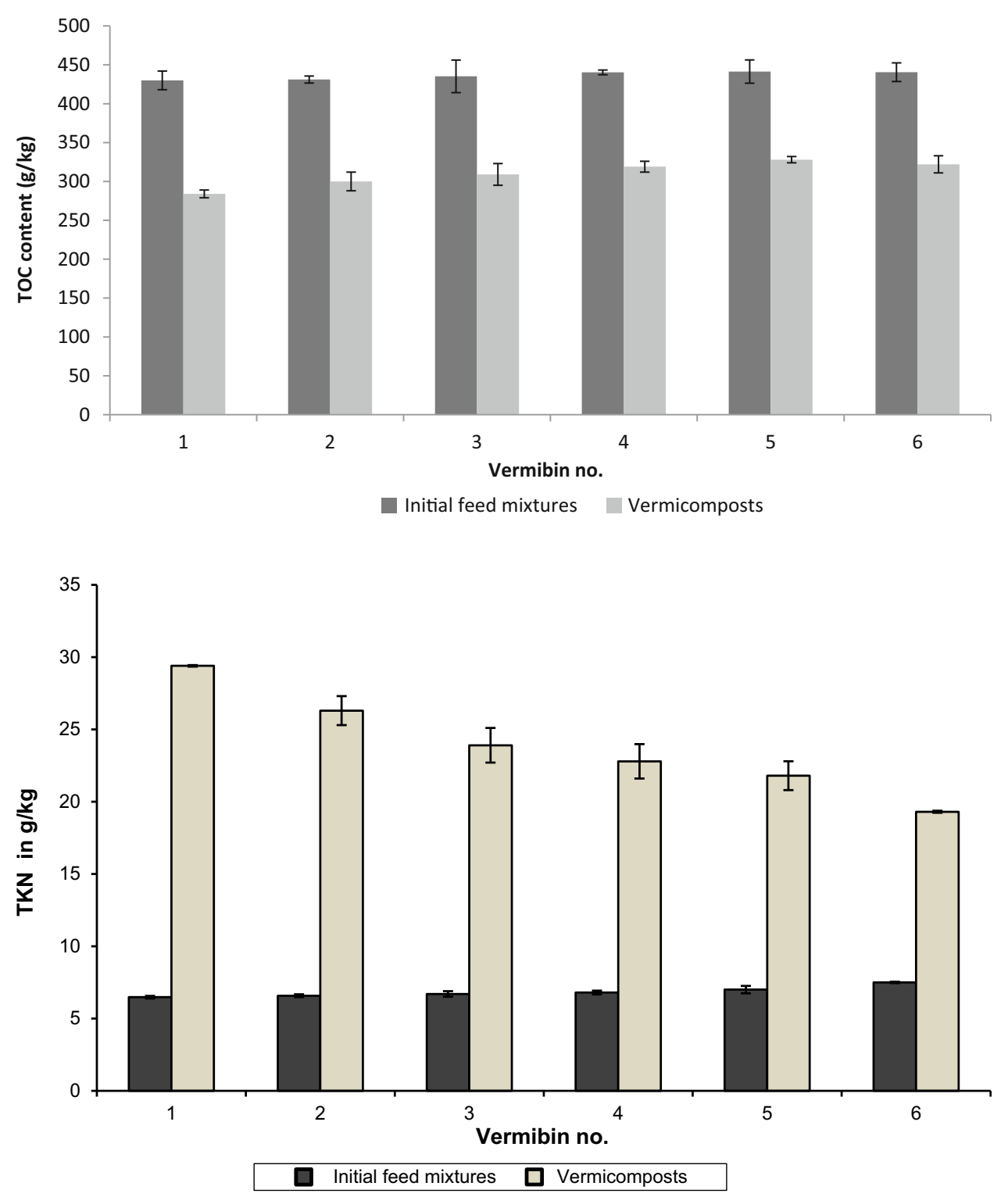

feed mixtures 3,4 and 5 were significantly different $(P<0.05)$. This increase in TKN content may be due to the discharge of mucus, nitrogenous substances, hormones, enzymes etc. by the worms (Tripathi and Bhardwaj 2004; Varma et al. 2015). Hartenstein and Hartenstein (1981) have reported that $\mathrm{pH}$ also plays an important role in retention of TKN by the vermicomposts as at higher $\mathrm{pH}$ it may be lost as ammonia.

$\mathrm{C}$ : $\mathrm{N}$ ratio of the waste material is important for microbial activity and worm fecundity. The $\mathrm{C}: \mathrm{N}$ ratio is key parameter, since plants do not assimilate mineral nitrogen unless this ratio is $\leq 20$ : 1 or less (Edwards and Bohlen 1996). The C: $\mathrm{N}$ ratio was significantly reduced in all the vermibins after vermicomposting (Fig. 4). Initial C: $\mathrm{N}$ ratio of waste mixtures was in the range of 58.7-66.3. Whereas $\mathrm{C}: \mathrm{N}$ ratio of vermicomposts was in the range of
9.65-16.68. Various authors have reported reduction in C: $\mathrm{N}$ ratio during vermicomposting in the 58-85\% (Gupta and Garg 2008). C: N reduction may be due to loss of TOC and gain in TKN during vermicomposting process.

\section{Heavy metal content in vermicomposts}

Heavy metals are known to have high residence time ranging from hundreds to thousands of years in the soil, and can be absorbed by plants and negatively affect human health after consumption (Coulibaly et al. 2014). Although some of the heavy metals in trace quantities are indispensable for plant growth, however, in higher concentrations may have damaging effects on crop yield and quality (Whittle and Dyson, 2002, Vodounnou et al. 2016). Therefore, heavy metals, in vermicompost, should be 
Fig. 4 C: $\mathrm{N}$ ratio of initial waste mixtures and vermicomposts in different vermibins

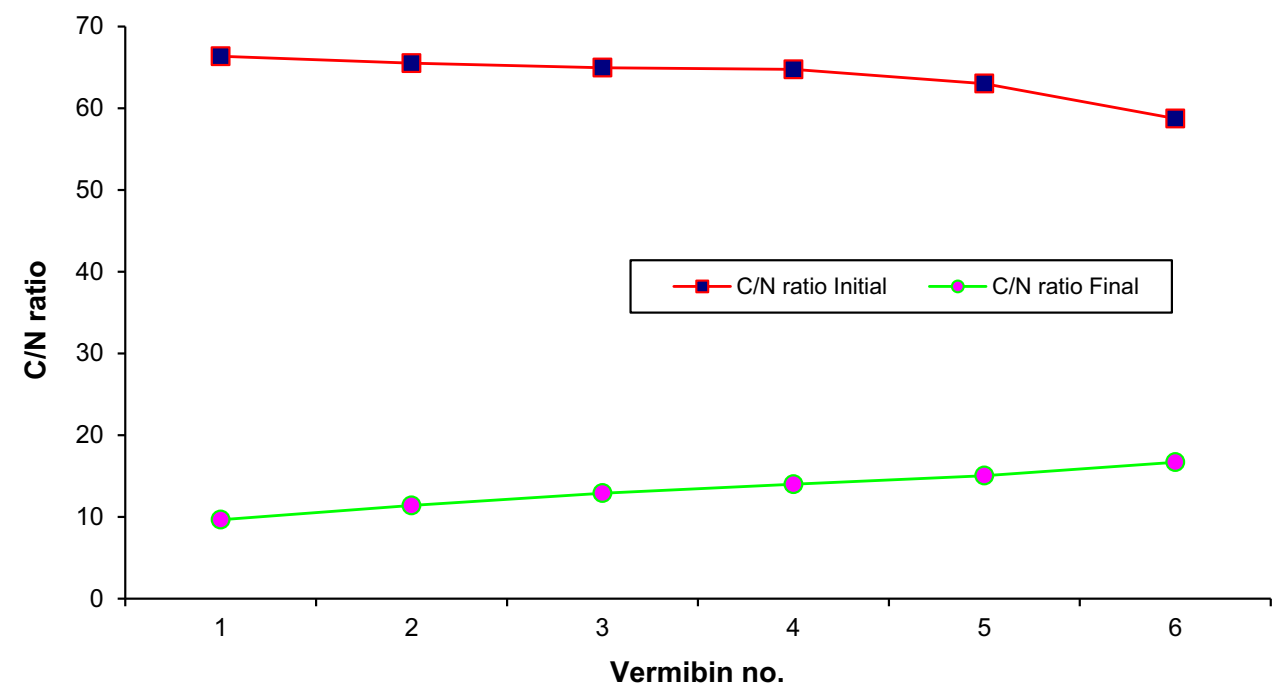

Table 4 Heavy metal content $\left(\mathrm{mg} \mathrm{kg}^{-1}\right)$ in initial waste mixtures and vermicomposts (mean $\pm \mathrm{SD}, n=3$ )

\begin{tabular}{lllllll}
\hline Vermibin no. & $\mathrm{Fe}$ & $\mathrm{Zn}$ & $\mathrm{Ni}$ & $\mathrm{Cu}$ & $\mathrm{Cr}$ & $\mathrm{Pb}$ \\
\hline \multicolumn{2}{l}{ Initial waste mixtures } & & & & & \\
1 & $5670 \pm 59$ & $172 \pm 3$ & $7.40 \pm 0.04$ & $31.7 \pm 0.5$ & $101 \pm 6.0$ & $7.70 \pm 0.01$ \\
2 & $5567 \pm 147$ & $168 \pm 2$ & $7.24 \pm 0.03$ & $31.0 \pm 0.6$ & $98.3 \pm 1.7$ & $7.74 \pm 0.02$ \\
3 & $5475 \pm 165$ & $164 \pm 5$ & $7.04 \pm 0.04$ & $30.5 \pm 0.0$ & $96.2 \pm 0.8$ & $7.74 \pm 0.02$ \\
4 & $5398 \pm 88$ & $160 \pm 5$ & $6.90 \pm 0.05$ & $30.5 \pm 0.3$ & $94.8 \pm 0.4$ & $7.76 \pm 0.01$ \\
5 & $5310 \pm 61$ & $156 \pm 2$ & $6.68 \pm 0.02$ & $29.8 \pm 0.2$ & $91.7 \pm 0.3$ & $7.80 \pm 0.04$ \\
6 & $5220 \pm 47$ & $151 \pm 2$ & $6.46 \pm 0.03$ & $28.4 \pm 0.6$ & $89.0 \pm 0.7$ & $7.80 \pm 0.03$ \\
Vermicompost & & & & & & \\
1 & $6842 \pm 129 \mathrm{c}$ & $210 \pm 9 \mathrm{~d}$ & $10.2 \pm 0.1 \mathrm{~d}$ & $43.5 \pm 1.4 \mathrm{~d}$ & $121 \pm 8 \mathrm{bc}$ & $8.15 \pm 0.13 \mathrm{c}$ \\
2 & $6773 \pm 131 \mathrm{c}$ & $198 \pm 2 \mathrm{~cd}$ & $10.2 \pm 0.2 \mathrm{~d}$ & $44.8 \pm 3.5 \mathrm{~d}$ & $124 \pm 6 \mathrm{c}$ & $8.55 \pm 0.13 \mathrm{~d}$ \\
3 & $6697 \pm 98 \mathrm{c}$ & $188 \pm 5 \mathrm{bc}$ & $10.8 \pm 0.3 \mathrm{e}$ & $38.9 \pm 1.1 \mathrm{c}$ & $108 \pm 1 \mathrm{a}$ & $8.43 \pm 0.07 \mathrm{~d}$ \\
4 & $6321 \pm 34 \mathrm{~b}$ & $184 \pm 6 \mathrm{~b}$ & $9.7 \pm 0.15 \mathrm{c}$ & $36.2 \pm 0.8 \mathrm{bc}$ & $110 \pm 3 \mathrm{ab}$ & $7.65 \pm 0.10 \mathrm{~b}$ \\
5 & $5878 \pm 89 \mathrm{a}$ & $181 \pm 1 \mathrm{~b}$ & $8.8 \pm 0.07 \mathrm{~b}$ & $32.7 \pm 0.4 \mathrm{ab}$ & $106 \pm 1 \mathrm{a}$ & $6.80 \pm 0.01 \mathrm{a}$ \\
6 & $5689 \pm 90 \mathrm{a}$ & $162 \pm 2 \mathrm{a}$ & $7.5 \pm 0.67 \mathrm{a}$ & $31.3 \pm 0.7 \mathrm{a}$ & $107 \pm 3 \mathrm{a}$ & $7.60 \pm 0.05 \mathrm{~b}$ \\
\hline
\end{tabular}

Mean values followed by the same letter(s) in a column within the raw mixtures or the vermicomposts are not significantly different at $P<0.05$ quantified prior to its application in agricultural soils. Heavy metals content in different waste mixtures and vermicomposts are given in Table 4 . The results showed that $\mathrm{Fe}, \mathrm{Zn}, \mathrm{Ni}, \mathrm{Cu}, \mathrm{Cr}$ and $\mathrm{Pb}$ content in the vermicomposts was higher than initial waste mixtures.

Total $\mathrm{Fe}$ content in waste mixtures was in the range of 5220 to $5670 \mathrm{mg} \mathrm{kg}^{-1}$ and in vermicompost, it ranged from 5689 to $6842 \mathrm{mg} \mathrm{kg}^{-1}$. It was $8.9-22.3 \%$ higher in vermicomposts than waste mixtures. The TFe content in vermicomposts was significantly different $(P<0.05)$, except for waste mixture 5 and 6 . Total $\mathrm{Zn}$ content in waste mixtures was in range of $151-172 \mathrm{mg} \mathrm{kg}^{-1}$ (Table 4). It was 7.2 to $22 \%$ higher in vermicomposts than raw mixtures. Minimum increase in TZn was noted in vermibin no. $6\left(162 \pm 2 \mathrm{mg} \mathrm{kg}^{-1}\right)$ and maximum in vermibin no. 1 $\left(210 \pm 9 \mathrm{mg} \mathrm{kg}^{-1}\right)$. Total $\mathrm{Ni}$ content in vermicomposts was in the range of $6.46-7.40 \mathrm{mg} \mathrm{kg}^{-1}$, which is $16-40.8 \%$ higher than raw mixtures. The TZn and TNi content in vermicomposts was significantly different $(P<0.05)$. Total $\mathrm{Cu}$ content was also 9.7 to $42.2 \%$ higher in vermicomposts. $\mathrm{TCu}$ content was maximum in vermibin no. $6\left(31.3 \pm 0.7 \mathrm{mg} \mathrm{kg}^{-1}\right)$ and maximum in vermibin no. $1\left(43.5 \pm 1.4 \mathrm{mg} \mathrm{kg}^{-1}\right)$. Similarly, total $\mathrm{Cr}$ content was also higher in vermicomposts than initial waste mixtures; it was in range of 106-124 mg kg-1 in vermicomposts and in range of $89-101 \mathrm{mg} \mathrm{kg}^{-1}$ in initial waste mixtures (Table 4). The $\mathrm{TCr}$ content in vermicomposts was not significantly different in waste mixture $3,4,5$ and 6 . Total $\mathrm{Pb}$ content was slightly higher in vermicomposts obtained from vermibin no. 1, 2 and 3, while it was lesser in the 
vermicomposts obtained from vermibin no. 4,5 and 6 as compared to initial. It was in range of $7.74-7.80 \mathrm{mg} \mathrm{kg}^{-1}$ in waste mixtures and in range of $6.80-8.55 \mathrm{mg} \mathrm{kg}^{-1}$ in (Table 4).

The total metal content may increase because of the carbon losses during vermicomposting (Dominguez 2004). Reduction in waste volume and quantities during vermicomposting may be another factor for enhanced levels of heavy metals in vermicompost (Gupta et al. 2007). Several studies have reported increase in metal content after vermicomposting of various organic wastes. Elvira et al. (1998) have reported the increase of $\mathrm{Zn}, \mathrm{Fe}, \mathrm{Mn}$ and $\mathrm{Ni}$ concentration in the vermicompost of paper-pulp mill sludge. Similarly, Varma et al. (2015) have reported increase in heavy metal concentration of waste carbide sludge (WCS) and agricultural waste after vermicomposting.

\section{Growth and reproduction of Eisenia fetida}

The worm's growth was good except little mortality in some vermibins. The worm mortalities in different vermibins were 1 to $5 \%$. In place of dead worms, new worms were added from the stock culture to maintain worm population. Higher mortality was observed in those vermibins, which had higher percentage of $\mathrm{PH}$. There was no mortality in vermibin 1 and 2. Figure 5 depicts the growth of the worms in different vermibins. In all the vermibins, initially there was an increase in worm biomass followed by stabilization, and, finally biomass loss. This initial increase in worm biomass may be due to food availability in plenty and in later stages, the biomass loss may be due to non-availability of the food to the worms. The biomass gain in different vermibins was inconsistent. Maximum worm biomass was observed in vermibin no. 1 and minimum worm biomass was in vermibin no. 6 . The results also showed that maximum worm biomass was attained on 36th day in vermibin no. 1 (Table 5). Mean net worm biomass gain $\left(1263 \pm 26 \mathrm{mg} \mathrm{worm}^{-1}\right)$ was also maximum in vermibin no. 1 and minimum $\left(874 \pm 15 \mathrm{mg} \mathrm{worm}^{-1}\right)$ in vermibin no. 6 .

The fecundity of earthworms in different vermibins has been encapsulated in Table 5. Cocoon production was started between 18th and 24th day of vermicomposting in different all the vermibins. After 60 days maximum cocoons $(383 \pm 25)$ were produced in vermibin no. 2 , followed by vermibin no. 1 and 3 (Table 5). Cocoon production was affected by the percentage of substrates in the vermibins. The number of cocoons produced per worm was also maximum in vermibin no. $2(7.6 \pm 0.25)$ and the minimum in vermibin no. $6(1.81 \pm 0.09)$. The maximum hatchlings were produced in vermibin no. $1(1030 \pm 181)$ and minimum in vermibin no. $6(260 \pm 17)$ (Table 5). The biomass of hatchlings was in the range of 80.2-16.7 $\mathrm{g}$ in different vermibins. Maximum hatchling biomass was in vermibin no. 1 and minimum in vermibin no. 2 . This showed that maximum growth and reproduction was in vermibin no. 1 (100\% BPS) and minimum in vermibin no. $6(50 \% \mathrm{BPS}+50 \% \mathrm{PH})$. The worm biomass growth and cocoons production were lesser in $\mathrm{PH}$ spiked waste

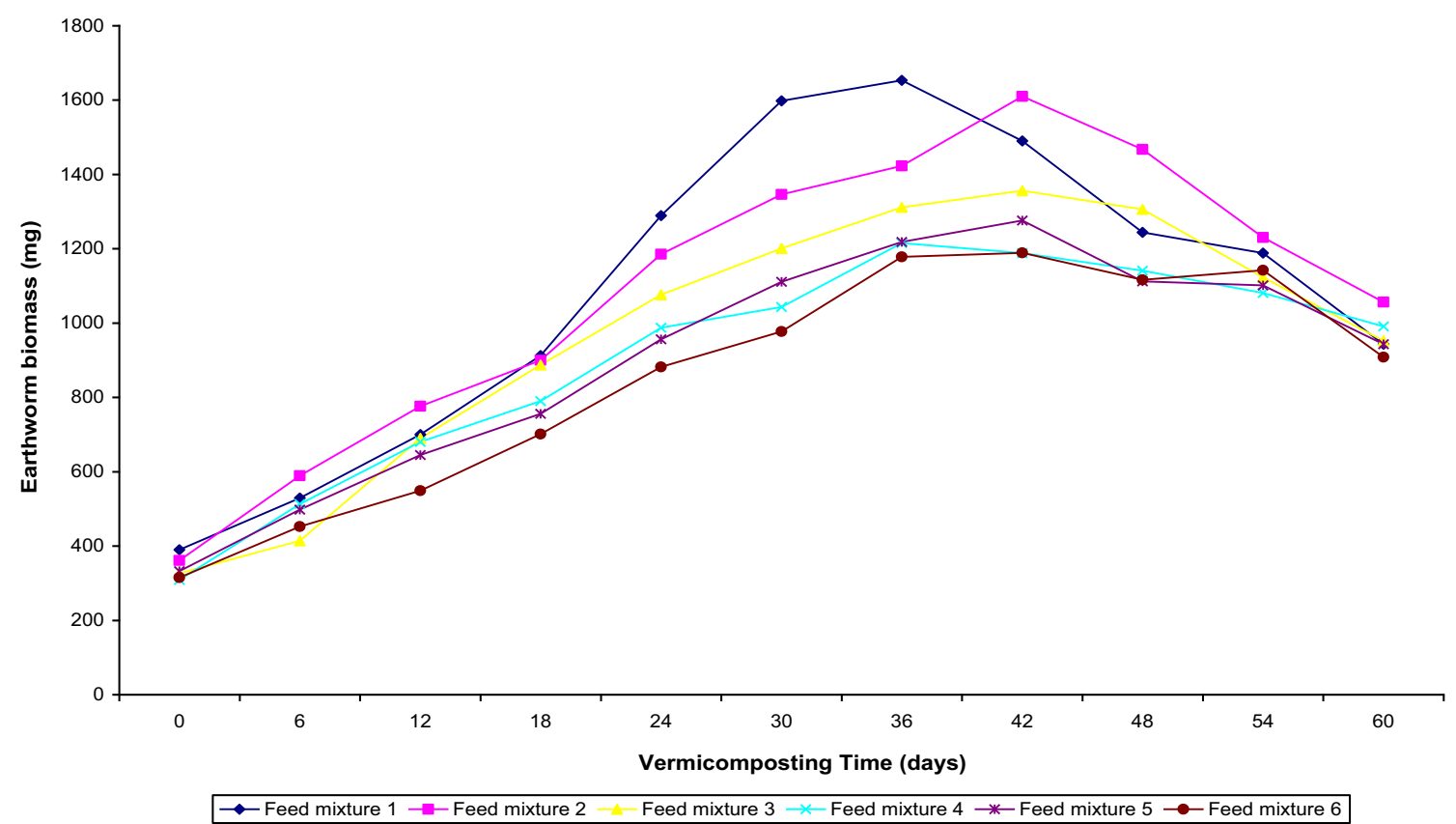

Fig. 5 Dynamics of worm biomass in different vermibins 


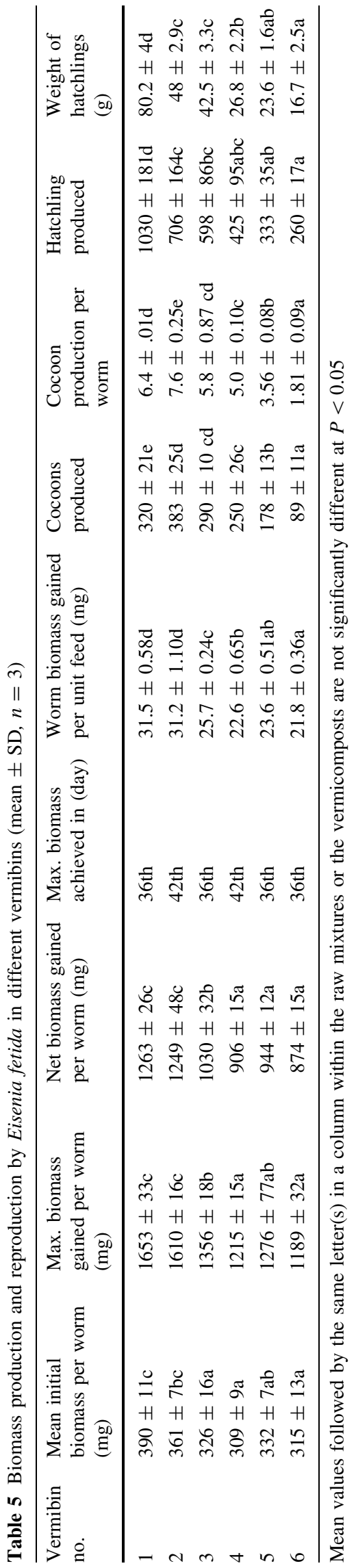

mixtures as compared to control (100\% BPS), though it demonstrated the positive approach for the utilization of $\mathrm{PH}$ in vermicomposting.

\section{Conclusion}

This study proved that parthenium mixed with biogas plant slurry could be profitably vermicomposted using earthworm Eisenia fetida. The NPK content of the vermicomposts was higher and their $\mathrm{C}: \mathrm{N}$ ratio was $<20$ indicating their significance for soil health. The data showed that physico-chemical characteristics of initial feed determine the nutritive value of vermicomposts. The earthworms have a respectable biomass gain and cocoon production in all vermibins, but the best results were shown by $100 \%$ biogas plant slurry than the other studied combinations. At higher concentrations, parthenium affects the decomposition efficiency of earthworms. It can also be inferred from the results that vermicomposting process may be integrated in the overall plan of parthenium control.

Open Access This article is distributed under the terms of the Creative Commons Attribution 4.0 International License (http://crea tivecommons.org/licenses/by/4.0/), which permits unrestricted use, distribution, and reproduction in any medium, provided you give appropriate credit to the original author(s) and the source, provide a link to the Creative Commons license, and indicate if changes were made.

\section{References}

Bear FE (1964) Chemistry of the Soil, 2nd edn. Reinhold Publishing Corporation, New York

Bezuneh TT (2015) Phytochemistry and antimicrobial activity of Parthenium hysterophorus L.: a review. Sci J Anal Chem 3(3):30-38. doi:10.11648/j.sjac.20150303.11

Bremner JM, Mulvaney RG (1982) Nitrogen total. In: methods of soil analysis. Am soc agron madison, wisconsin. Page AL, Miller RH, Keeney DR (eds), pp 575-624

Coulibaly SS, Kouassi KI, Tondoh EJ, Zoro BIA (2014) Influence of the population size of the earthworm Eudrilus eugeniae on the heavy metal content reduction during vermicomposting of animal wastes. App Sci Report 3(2):96-103. doi:10.15192/ PSCP.ASR.2014.3.2.96103

Dominguez J (2004) State of the art and new perspectives in vermicomposting research. In: Edwards CA (ed) Earthworm Ecology, 2nd ed. CRC Press, Boca Raton, 2004: pp 401-425. doi:10.1201/9781420039719.ch20

Edwards CA, Bohlen PJ (1996) Biology and ecology of earthworm, 3rd edn. Chapman and Hall, New York

Edwards CA, Fletcher KE (1988) Interactions between earthworms and microorganisms in organic matter breakdown. Agric Ecosyst Environ 24:235-247. doi:10.1016/01678809(88)90069-2

Elvira C, Sampedro L, Benitez E, Nogales R (1998) Vermicomposting of sludges from paper mill and dairy industries with Eisenia andrei: a pilot scale study. Bioresour Technol 63:205-211. doi:10.1016/S0960-8524(97)00145-4 
Goswami L, Patel AK, Dutta G, Bhattacharyya P, Gogoi N, Bhattacharya SS (2013) Hazard remediation and recycling of tea industry and paper mill bottom ash through vermiconversion. Chemosphere 92(6):708-713. doi:10.1016/j.chemosphere.2013. 04.066

Gunaseelan VN (1998) Impact of anaerobic digestion on inhibition potential of parthenium solids. Biomass Bioenerg 14(2):179-184. doi:10.1016/S0961-9534(97)10019-8

Gupta R, Garg VK (2008) Stabilization of primary sewage sludge during vermicomposting. J Hazard Mater 153:1023-1030. doi:10.1016/j.jhazmat.2007.09.055

Gupta R, Mutiyar PK, Rawat NK, Saini MS, Garg VK (2007) Development of a water hyacinth based vermireactor using an epigeic earthworm E. foetida. Bioresour. Technol. 98: 2605-2610. http://dx.doi.org/10.1016/j.biortech.2006.09.007. Accessed 09 Mar 2016

Hartenstein R, Hartenstein F (1981) Physicochemical changes effected in activated sludge by the earthworm Eisenia foetida. J Environ Qual 10:377-382. doi:10.2134/jeq1981. $00472425001000030027 x$

Kaviraj, Sharma S (2003) Municipal solid waste management through vermicomposting employing exotic and local species of earthworms. Bioresour Technol 90:169-173. doi:10.1016/S09608524(03)00123-8

Khaliq A, Aslam F, Matloob A, Hussain S, Tanveer A, Alsaadawi I, Geng M (2015) Residual phytotoxicity of parthenium: impact on some winter crops, weeds and soil properties. Ecotoxicol Environ Safe 122:352-359. doi:10.1016/j.ecoenv.2015.08.019

Kishore P, Ghosh AK, Singh S, Maurya BR (2010) Potential use of parthenium (Parthenium hysterophorus L.) in agriculture. Asian. J Agric Res 4(4):220-225. doi:10.3923/ajar.2010.220.225

Ko HJ, Ki KY, Hyeon KT, Chi KN, Umeda M (2008) Evaluation of maturity parameters and heavy metal contents in composts made from animal manure. Waste Manag 28:813-820. doi:10.1016/j. wasman.2007.05.010

Lee KE (1992) Some trends and opportunities in earthworm research or: darwin's children-the future of our discipline. Soil Biol Biochem 24:1765-1771. doi:10.1016/0038-0717(92)90185-Z)

Nallathambi GV, (1998) Impact of anaerobic digestion on inhibition potential of Parthenium solids. Biomass Bioenerg 14 (2): 179-184. doi:10.1016/S0961-9534(97)10019-8

Ndegwa PM, Thompson SA, Das KC (2000) Effects of stocking density and feeding rate on vermicomposting of biosolids. Bioresour Technol 71:5-12. doi:10.1016/S0960-8524(99)000553

Nelson DW, Sommers LE (1982) Total carbon and organic matter. In. Method of soil analysis. American society of agronomy. Page AL, Miller RH, Keeney DR (eds) Madison, pp 539-579

Pigatin LBF, Atoloye IA, Obikoya OA, Borsato AV, Rezende OO (2016) Chemical study of vermicomposted agroindustrial wastes. Int J Recycl Org Waste Agricult 5:55-63. doi:10.1007/s40093016-0117-7
Prakash M, Karmegam N (2010) Vermistabilization of pressmud using Perionyx ceylanensis mich. Bioresour Technol 101:8464-8468. doi:10.1016/j.biortech.2010.06.002

Rajiv P, Rajeshwaria S, Yadav RH, Rajendran V (2013) Vermiremediation: detoxification of parthenin toxin from parthenium. J Hazard Mater 262:489-495. doi:10.1016/j.jhazmat.2013.08.075

Ravindran B, Contreras-Ramos SM, Sekaran G (2015) Changes in earthworm gut associated enzymes and microbial diversity on the treatment of fermented tannery waste using epigeic earthworm Eudrilus eugeniae. Ecol Engg 74:394-401. doi:10.1016/j. ecoleng.2014.10.014

Roca-Pérez L, Martínez C, Marcilla P, Boluda R (2009) Composting rice straw with sewage sludge and compost effects on the soilplant system. Chemosphere 75:781-787. doi:10.1016/j.chemo sphere.2008.12.058

Suthar S (2006) Potential utilization of Guar gum industrial waste in vermicompost production. Bioresour Technol 97:2474-2477. doi:10.1016/j.biortech.2005.10.018

Suthar S (2010) Potential of domestic biogas digester slurry in vermitechnology. Bioresour Technol 101:5419-5425. doi:10. 1016/j.biortech.2010.02.029

Tripathi G, Bhardwaj P (2004) Comparative studies on biomass production, life cycles and composting efficiency of Eisenia foetida (Savigny) and Lampito mauritii (Kinberg). Bioresour Technol 92:275-278. doi:10.1016/j.biortech.2003.09.005

Varma VS, Yadav J, Das S, Kalamdhad AS (2015) Potential of waste carbide sludge addition on earthworm growth and organic matter degradation during vermicomposting of agricultural wastes. Ecol Engg 83:90-95. doi:10.1016/j.ecoleng.2015.05.050

Vodounnou DSJV, Kpogue DNS, Tossavi CE, Mennsah GA, Fiogbe ED (2016) Effect of animal waste and vegetable compost on production and growth of earthworm (Eisenia fetida) during vermiculture. Int J Recycl Org Waste Agricult 5:87-92. doi:10. 1007/s40093-016-0119-5

Whittle AJ, Dyson AJ (2002) The fate of heavy metals in green waste composting. Environmentalist 22:13-21. doi:10.1023/A: 1014563807198

Yadav HR (2015) Assessment of different organic supplements for degradation of Parthenium hysterophorus by vermitechnology. J of Environ Health Sci Engg 13(44):1-7. doi:10.1186/s40201015-0203-1

Yadav A, Garg VK (2009) Feasibility of nutrient recovery from industrial sludge by vermicomposting technology. J Hazard Mater 168:262-268. doi:10.1016/j.jhazmat.2009.02.035

Yadav A, Garg VK (2011) Vermicomposting - An effective tool for the management of invasive weed Parthenium hysterophorus. Bioresour Technol 102:5891-5895. doi:10.1016/j.biortech.2011. 02.062

Yadav A, Garg VK (2013) Nutrient recycling from industrial solid wastes and weeds by vermiprocessing using earthworms. Pedosphere 23(5):668-677. doi:10.1016/S1002-0160(13)60059-4 